\title{
Influence of information availability and utilization on decision-making of managers in large-scale manufacturing industries in Nigeria
}

\author{
S. O. Popoola', \\ Department of Library, Archival and Information Studies \\ University of Ibadan, Ibadan, Nigeria
}

\begin{abstract}
Received: $9^{\text {th }}$ December 2005
Accepted: 8th February 2006

This paper focuses on the influence of information availability and utilization on decision-making of managers in largescale manufacturing industries in Nigeria. Quota sampling with equal allocation method is used to select 650 managers from the 13 large-scale manufacturing industries that are quoted on the Nigerian Stock Exchange out of which 580 responded. The response rate achieved was 89.2 percent. The study found that information availability and information utilization simultaneously do significantly influence decision-making of the respondents $(F=28.98, d f=2 ; 577, p<$ $0.05)$; and that information availability $(b=0.5228, d f=577, T=8.08, p<0.05)$ and information utilization $(b=$ 0.7432, of $=577, T=12.47, P<0.05$ ) each independently has significant influence on decision-making of the respondents. Nevertheless, the study found that there is a significant multiple relationship between information availability, information utilization and decision-making of the managers in the large-scale manufacturing industries in Nigeria $(R=0.8386, P<0.05)$. The study recommends that the board of management in these industries should make wide range of relevant information resources available for use of managers in their decision-making. And those managers must intensify their efforts in making intensive use of information in their decision-making.
\end{abstract}

Key words: Information availability, information utilization, managers, manufacturing industries, Nigeria.

\section{Introduction}

For the purpose of this study, information is defined as processed data, facts, ideas, knowledge and messages contained in published or unpublished sources and either communicated orally or in printed forms which enable the receiver or user to be better informed about issue, topics, problems or events. Information utilization is operationalised as a situation where information is received and applied by the managers for decision-making analysis. Information availability is defined as abundance of physical presence of various sources from which information comes to the attention of managers in their decision-making analysis. Decision-making is operationalised as finding occasions for taking decisions, finding possible courses of action, selecting among courses of action and assessing past choices. In a nutshell, it is the point at which plans, policies and objectives are translated into concrete actions (Appleby, 1994).

Since the implementation of structural adjustment programme in 1986 to correct structural imbalance and achieve balanced economic development in Nigeria, managers in manufacturing industries have been facing a lot of problems in their business operations. These problems are high interest rates, inadequate or shortage of skilled manpower, rapid depreciation of Naira (Nigerian Currency) against foreign currencies, frequent changes in technology, consumers' low income, poor investment opportunities in the domestic economy, poor infrastructural facilities such road networks, telecommunications, air and water traffic systems, bad tax system, restrictive monetary policies, importation of capital goods restriction, lack of functional information highways, political instability and financial crimes. In this regard, the managers in the Nigerian manufacturing industries have to contend with high business risks due to business uncertainty. It is the uncertainty in the business environment of the managers world-wide that calls for rational decision-making. Rational decision-making cannot be done without sufficient and reliable information that is available and accessible for the utilization by the managers in business organizations like manufacturing industries.

Notably, most manufacturing industries do not survive under the hard economic conditions in African countries especially Nigeria because they fail to invest on information that is reliable, relevant, complete and unbiased to aid their decision-making processes. What Aiyepeku (1989) stressed some ten years ago is still relevant today. He contends that efficient decision-making is a function of the amount, accuracy, and timeliness of relevant information utilized in the process of taking decisions. It is widely felt that information is a critical factor input in the production process of manufacturing industries. Therefore, at every stage of production processes, decisions have to be made on efficient allocation of resources and the best line of production to select for maximum output of goods. When information is readily made available and used in the decision analysis of the managers in the manufacturing industries, the best alternative course of actions is chosen either for improved workers' productivity or profit making.

I. S. O. Popoola,PhD, is a Lecturer in the Department of Library, Archival and Information Studies, University of Ibadan, Nigeria.

e-mail:drpopoolaso@yahoo.co.uk

SA Jnl Libs \& Info Sci 2006, 72(1) 
Nonetheless, the primary functions of managers in the business organizations are planning, decision-making and controlling. These critical functions make the work activities of the managers in the manufacturing industries to be highly information intensive. Arguably, the modern day business managers especially in the developed countries of the world today have placed information on a higher pedestal than land, labour, capital, energy and technology. Thus, information is a crucial means of production in the knowledge economy. They regularly seek for needed information from their business environment, acquire it and make use of it to monitor, forecast, and evaluate their business performance as well as assess the consequence of their decision-making. It must be borne in mind that every manager in a manufacturing industry is a decision-maker. Mcfarland (1964) views decision-making as a whole lengthy, complex process of alerting, exploring and analyzing that precedes the final moment at which decision is made. Thus, the process involves: the past in which problems develop, information accumulates, and the need for a decision is perceived; the present in which alternatives are found and the choice is made; and the future in which decisions are carried out and evaluated.

Norton (1999) remarks that information is the bread and butter of business. Indeed information availability and its acquisition for use give economic and political power to the managers in business organizations like manufacturing industries. Thus, the power to achieve things, to take advantages of business opportunities, and to control people as well as making sound decisions. The remarkable success achieved by the multinational companies over the small and medium scale enterprises in the developing economies could be attributed to information acquisition and use in their decisionmaking analysis. Even the dominance of the market by the large scale business organizations making it impossible for the small and medium scale enterprises to penetrate the market or to increase their market shares can be traced to the high premium placed on information acquisition and use for rational decision-making, creativity and innovation and improved productivity. Eyitayo (1998) states that information naturally creates inequalities among people, organizations and nations.

Adelabu and Adisa (2003) submit that managers require information in order to be able to make interpersonal judgments. Managers in business organizations most frequently experience information overload. Much discretion needs to be exercised on the part of the managers and information filtering should be done in order to ensure that relevant, reliable and accurate information are used for rational decision - making when faced with information overload. The frequency of use of a particular information source by managers in business organizations perhaps depends on its information richness. Managers operate within their business environment. The business environment of managers may be defined as the totality of physical and social factors that influence the growth of their organization. Be that as it may, the managers must seek and collect reliable information from its business environment in order to make effective decisions. Abels (2002) asserts that all organizations need to monitor at some level what goes on in their environment and recognize their strengths and weakness in relation to it. The importance of environmental information depends on the degree to which the success of the organization itself depends on its environment. Information availability and accessibility is fundamental for monitoring the events that occur in the business environment of the manager in an organization. Due to perceive environment sectors' uncertainty (customers, suppliers, technical, social, legal, political, cultural, geographical and economic), managers require information from formal and informal sources to make effective decisions. Studies conducted in Nigeria over the past two decades provide some similar results to those originating from this study. For example, Alli (2000) reports that managers in the Nigerian banking industry sourced their needed information from stock brokers, colleagues and company's reports. Sawyer (1993) finds that executive managers in the Nigerian manufacturing industries used impersonal sources of information - memoranda, feasibility reports, company library and electronic information services for their business performance.

A review of past studies in Librarianship and Information Science as well as organizations behavior theory, have shown that African business information researchers have not shown appreciable interest on how information availability and utilization affect the business performance of corporate organizations; and decision-making of managers there in. It is against this backdrop that this study investigates the influence of information availability and utilization on decision-making of managers in large-scale manufacturing industries in Nigeria. The research hypothesis formulated and tested at $=0.05$ level of significance to guide the of this study were that there is no significant relationship between work experience and information utilization in decision making of managers in the large-scale manufacturing industries in Nigeria, there is no significant relationship between management cadre and information utilization in decision-making of managers in largescale manufacturing industries in Nigeria, there is no significant relationship between management cadre and information availability in decision-making of managers in the large-scale manufacturing industries in Nigeria, information availability and utilization simultaneously do not significantly influence decision-making of managers in large-scale manufacturing industries in Nigeria, information availability and information utilization do not equally influence decision-making of managers in the large-scale-manufacturing industries in Nigeria and finally that there is no significant multiple relationship between information availability, information utilization and decision-making of managers in large-scale manufacturing industries in Nigeria. 


\section{Literature review}

Managers in business organizations are compelled to seek and obtain information from the available sources and use it to manage uncertainties that may adversely affect their organizational effectiveness and business success. The nature of business uncertainty, information sources available for use, information capacity utilization, level of education and nature of job performance may affect decision-making of the managers in business organizations like manufacturing industries. Aiyepeku (1978) stresses that the decision-makers' personality variables; time the decision is being made; and the environment in which the decision has to be made will affect the decision-makers' use of information. Tiamiyu (1990) opines that source use is related to some characteristics of work activities, the availability and adequacy of sources and some attributes of the source and information users. Managers in manufacturing industries are potential users of information to coordinate the work activities of their subordinates, to allocate scarce resources efficiently through better decision-making. Opeke (1984) stresses the importance of the ability of a manager in an organization to put him/herself in such a position as to contact relevant information sources that are likely to be related to the operations and services provided by his/her organization and the manager's ability to select appropriate information sources to resolve a specific decision situation at a given time. Be that as it may, a manager without good information handling skills will find it difficult to locate and retrieve needed information from the numerous available information sources to make strategic decisions.

Nonetheless, Robson (1997) posits that an analysis of the environment is important because it increases the quality of the strategic decision-making of the managers by considering a range of the relevant features well before the need to make an irrevocable decision. He stresses further that the success of an environmental analysis is largely dependent upon the characteristics of that environment: the complexity of it, that is, how many variables are in the environment, the rate of change and the amount (and cost) of available information about it. Information availability, accessibility and utilization assist the business managers in manufacturing industries to carry out effective environmental analysis. Popoola (2002a) asserts that creating new concepts, identifying problems, solving problems, planning initiating, decision-making, controlling, and searching are just some of the purposes to which information is directed towards human activity in industrial organization. Due to information processing limitations and problem pressures, much organizational decisionmaking is largely "muddling through" satisfying with limited information, succumbing to time limits (Grosser, 1991). The many bounds on rational decision-making include: ambiguous goals defined incrementally, need to satisfy, availability of possible solutions and actions, and social conflict, and political obstacles (Katzer and Fletcher, 1992).

The economic theory of information suggests to us that as long as the marginal value of information exceeds its marginal cost of information, users would continue to demand and use information (products or services) either for decision-making, problem solving or to perform their task complexity. Business managers in manufacturing industries would continually demand and use information for their decision analysis so far that they derive maximum utility from its usage.

Therefore the success of managers in industrial organizations depends on how much information is available to them from variety of sources which include personal and impersonal sources. The ability of corporate libraries to provide the relevant, current and timely information to reduce business failure and help the organizations to gain competitive edge over others is very important. In Nigeria to day, there are poor industrial organizations because such firms have no access to current and reliable information to face stiff market competition from their competitors, and make strategic decisions necessary for profit making. Mabawonku and Oladele (200l) are of the opinion that information is of value to the extent that it can be used for decision-making. They further elaborate that for a piece of information to be of value, it must be accurate, timely, and up-to-date and packaged in a format that can readily commend it to easy assimilation by the targeted audience. Akhtar and Melesse (1994) submit that African decision-makers and policy formulators need pertinent, accurate and timely information in order to make informed decisions. Over four decades ago, Brewer and Tomlinson (1964) suggested that the greatest fear a manager has is being caught without information; consequently, managers spend most of their time accumulating information.

These early studies also shows some important differences in the information behaviors of senior-level managers versus lower-level managers in any business organization. Due to their level, senior-level managers are expected to deal with strategic and ill-structured problems (Gorry, Scott and Micheal, 197I). Thus, they have different needs for and sources of information, for example external versus internal, and soft versus hard information; and they exert more effort to make sense of that information (O' Reilly and Pondy 1979; Perkins and Rao, 1990). Kanter (1989) states that "the ability of managers to get things done depends more on the numbers of networks in which they are centrally involved than on their height in a hierarchy. As managers increase their involvement in networks, they increase the number of channels available to them for strategic contacts. They then have more information available to them and greater opportunities to initiate action. Many managers in industrial organizations like the manufacturing industries have limited time to search for pertinent information necessary and relevant to their decision-making and so make decisions on their 
intuition. The wrong decision made due to lack of information use often times lead to business failure. Popoola (1993) opines that the success of organization depends on the quality and quantity of information that is timely available in the relevant areas of its business operations. Marshall (1993), Naylor (1988) and Pellow and Wilson (1993) posits that corporate information systems providing relevant information products and services for the use of business organizations improved their business performance through decision-making. Popoola (1996) study of statistical information needs of industries in Nigeria found that they used statistical information for financial management, personnel management, product development and planning and project management and evaluation.

Moreover, in organization theory, emphasis is usually placed on the utilization of information by managers in decisionmaking and planning. Most managers see information as being homogeneous commodity but the information coming to the attention of the managers from business environment are heterogeneous in nature. They have problems of accuracy, reliability, relevance, completeness, sufficiency, efficiency and timeliness. Consequently, business managers would prefer to use information sources that are available, relevant and of good quality in their decision-making processes. Okwilagwe (2000) investigated information service packages preferred by managers in book publishing organizations in Nigeria and reported that they preferred full length of original documents, summary of original documents (abstracts), evaluative (critical) review of original documents and descriptive review of original documents. Previous studies has shown that although managers use multiple types of information for decision making, they rely on oral sources most frequently due to their high level of perceived credibility and accessibility (Huber and Daft, 1987, Tyler and Bettenhausen, 1989). Miller (1994) reports that difference in organization values influenced the frequency with which decision-makers in manufacturing firms in North America used oral, written, and electronic sources of information for environmental scanning. Auster and Choo (1994) in their study of how chief executive officers in the Canadian publishing and telecommunications industries acquire and use information about the business environment finds that personal sources are very important and that the most frequently used personal sources of information by them are subordinate managers, subordinate staff, customers and business associates. Similarly, Popoola (2002b) investigation of female managers information input to decision-making in oil companies in Nigeria found that there was a significant difference between top level and middle level female managers' information input to corporate decision-making. Olatunji (1994)_study of availability and utilization of information sources in Cadbury Nigeria Plc, Lagos and found that information services available for the use of senior staff and managers are current awareness services, photocopying and technical services while the primary sources of information used are periodicals, research reports and company files.

Perhaps, one of the major problems responsible for poor decision-making of managers in business organizations in Nigeria is non-availability and utilization of relevant business information. Those ones that are made available to the managers are hardly meet characteristics of reliable information.

\section{Method}

The descriptive research design was used in this study. The study population comprised of managers in the 13 selected large-scale manufacturing industries with headquarters in Lagos, Nigeria. They are leading and notable manufacturing industries that are quoted in the Nigerian Stock Exchange. The quota sampling with equal allocation method was used to select 50 managers each from the 13 chosen large-scale manufacturing industries. A set of questionnaire called entitled "Information Availability, Utilization and Decision-making of Managers (IAUDM)" scale was used for data collection. The research instrument had three main sections. Section 'A' focused on demographic information of the respondents such as sex, age, marital status, work experience (in years), academic qualifications, and management cadre; and information needs in decision-making of the respondents. Section 'B' dealt with information availability and utilization in decisionmaking of the respondents. Sixteen sources of information that are considered relevant to the decision-making of the respondents were provided. Information availability was measured on a-point scale by asking the respondents to score each source type as follows: very readily available $=4$, readily available $=3$, occasionally available $=2$ and not available $=\mathrm{I}$. Information utilization was equally measured on a 4-point scale by asking the respondents to score each source type as follows: - very highly utilized $=4$, highly utilized $=3$, occasionally utilized $=2$ and not utilized $=1$. This subscale had a coefficient reliability of 0.84 using Cronbach- alpha method. Section ' $C$ ' dealt with decision-making of the respondents. It is a -26 item decision-making behaviour inventory developed by Hammed (2002). It was revalidated and a reliability coefficient of 0.78 was obtained using cronbach-alpha method. It is a 5 - point scale with response ranging from very much unlike $\mathrm{me}=\mathrm{I}$ to very much like $\mathrm{me}=5$. The overall reliability coefficient of the research instrument used was $=$ 0.82 based on Cronbach-alpha method. The postgraduate research assistants were drawn from postgraduate students in the Department of Library, Archival and Information Studies, University of Ibadan. They personally administered the questionnaire on the 650 sampled managers from the 13 chosen large-scale manufacturing industries with headquarters at Lagos out of which 580 responded and their questionnaire were found valid for analysis. The response rate achieved 
was 89.2 percent. The questionnaire administration and retrieval is reflected in Table I. The data collection lasted for two months (i.e. May-June, 2004)

Table I Questionnaire Administration and Retrieval $(\mathrm{N}=650)$

\begin{tabular}{llll}
\hline Companies / Industries & Number Sampled & Number Responded & Response Rate \\
\hline Dunlop Nig. Plc. & 50 & 40 & 80 \\
Nigerian Breweries, Plc. & 50 & 50 & 100 \\
Cadbury Nig. Plc. & 50 & 50 & 100 \\
Nigerian Bottling Company, Plc. & 50 & 50 & 100 \\
Nestle Nig. Plc. & 50 & 35 & 70 \\
United African Nig. Company, Plc. & 50 & 50 & 100 \\
7-Up Bottling Company, Plc. & 50 & 50 & 100 \\
Nigerian Textiles, Plc. & 50 & 38 & 76 \\
West African Portland Company, Plc. & 50 & 50 & 100 \\
Guinness Nig. Plc. & 50 & 50 & 100 \\
Berger Paints, Plc. & 50 & 40 & 80 \\
May \& Baker Nig. Plc. & 50 & 30 & 60 \\
Lever Brothers Nig. Plc. & 50 & $\mathbf{4 7}$ & 94 \\
\hline Total & $\mathbf{6 5 0}$ & $\mathbf{5 8 0}$ & $\mathbf{8 9 . 2}$ \\
\hline
\end{tabular}

The data collected from the field were analysed using descriptive statistical tools-mean, standard deviation and variance as well as inferential statistics - pearson's zero order correlation and multiple regression analysis with the aid of computer and software package for social sciences (SPSS).

\section{Results}

Of the 580 respondents, 198 (34.1\%) were female while the remaining $382(65.9 \%)$ are male. The main dominance of male in management positions of these large-scale manufacturing industries in Nigeria could be attributed to much discrimination against women and low percentage of highly educated female personnel in the management cadres of the most large-scale manufacturing companies in Nigeria. The result of data analysis carried out showed that out that of the 580 respondents, 185 (31.9\%) were single and 395(68.1\%) were married. The ages of the respondents ranged between 32 and 53 years with mean age $=34.4, \mathrm{SD}=3.8$ years. Their working experience was between 5 and 34 years (with mean $=18.5, S D=4.2)$ years. In addition, of the 580 respondents, $175(30.2 \%)$ had bachelor degree qualifications or its equivalents, 182(31.4\%) had achieved postgraduate diploma qualification, 202(34.8\%) were holders of master's degree certificates and $2 \mathrm{I}(3.6 \%)$ had obtained a doctor of philosophy (Ph.D) degree qualifications. One can therefore infer that the sampled large-scale manufacturing industries are blessed with highly knowledgeable human resources.

Concerning the information needs of the respondents, they were provided with a list of types of information, which managers may need in support of their decision-making in business organizations. And they were requested to score each information type on a 4-point scale in the following manner; very highly needed $=4$, highly needed $=3$, occasionally needed $=2$ and not needed $=1$. Table 2 depicts the mean, standard deviation and variance scores of information needs in decision-making of the respondents. The most prevailing information needs in decision-making of the respondents are industry information $(X=3.96, S D=0.24 I)$ company information $(X=3.94, S D=0.222)$, economic forecasts $(X=$ $3.94, S D=0.220)$, legal or regulatory information $(X=3.93, S D=0.216)$, information on technology $(X=3.92, S D=$ $0.212)$, and population matters $(X=3.90, S D=0.208)$.

Table 2 Mean scores of information needs in decision-making of the respondents

\begin{tabular}{|c|c|c|c|}
\hline Type of Information & $\mathbf{x}$ & SD & Variance \\
\hline Industry information & 3.96 & 0.241 & 0.058 \\
\hline Company information & 3.94 & 0.222 & 0.049 \\
\hline Legal and regulatory information & 3.93 & 0.216 & 0.047 \\
\hline Economic forecast & 3.94 & 0.220 & 0.048 \\
\hline Information on technology & 3.92 & 0.212 & 0.045 \\
\hline Population matters & 3.90 & 0.208 & 0.043 \\
\hline Management issues & 3.84 & 0.186 & 0.035 \\
\hline Labour matters & 3.80 & 0.188 & 0.035 \\
\hline Environmental management & 2.94 & 0.128 & 0.016 \\
\hline Political matters & 2.92 & 0.132 & 0.017 \\
\hline Socio-cultural information & 2.60 & 0.098 & 0.010 \\
\hline
\end{tabular}

Table 3 shows the mean, standard deviation and variance scores of information sources availability to respondents in their decision-making. The major sources of information available to them when taking decisions are customers $(X=3.99$, SD 
$=0.219)$, colleagues $(X=3.97, S D=0.211)$, subordinate staff $(X=3.97, S D=0.214)$, Trade literature $(X=3.96, S D$ $=0.218)$, Company library $(X=3.94, S D=0.182)$, Newspapers/magazines $(X=3.94, S D=0.176)$, Textbooks/journals $(X=3.92, S D=0.174)$, Company files $(X=3.90, S D=0.284)$, electronic information services $(X=3.90, S D=0.360)$ and internal memoranda/circulars $(X=3.88, S D=0.318)$. This implies that these information sources are very readily available to them in their decision-making.

Table 3 Mean scores of information sources availability in decision-making of the respondents

\begin{tabular}{|c|c|c|c|}
\hline Information Sources & $\mathbf{x}$ & SD & Variance \\
\hline Customers & 3.99 & 0.219 & 0.048 \\
\hline Colleagues & 3.97 & 0.211 & 0.045 \\
\hline Subordinate staff & 3.97 & 0.214 & 0.046 \\
\hline Trade literature & 3.96 & 0.218 & 0.048 \\
\hline Company library & 3.94 & 0.182 & 0.033 \\
\hline Company library & 3.94 & 0.182 & 0.033 \\
\hline Newspapers/magazines & 3.94 & 0.176 & 0.031 \\
\hline Textbooks/journals & 3.92 & 0.174 & 0.030 \\
\hline Company files & 3.90 & 0.284 & 0.081 \\
\hline Electronic information services & 3.90 & 0.360 & 0.130 \\
\hline Internal memoranda/circulars & 3.88 & 0.318 & 0.101 \\
\hline Radio/Television & 2.86 & 0.216 & 0.047 \\
\hline Government publications & 2.82 & 0.324 & 0.105 \\
\hline Patents/standards & 2.81 & 0.312 & 0.097 \\
\hline Reports & 2.78 & 0.218 & 0.048 \\
\hline Competitors & 1.74 & 0.146 & 0.021 \\
\hline Business/professional associates & 1.72 & 0.152 & 0.023 \\
\hline
\end{tabular}

Table 4 presents the mean, standard deviation and variance scores of information sources utilization in decision-making of the respondents. The most prevailing information sources utilization of the respondents when taking decisions in their respective industries/companies were colleagues $(X=3.96, S D=0.314)$, followed by subordinate staff $(X=3.95, S D=$ $0.310)$, Customers $(X=3.93, S D=0.272)$, company files $(X=3.93, S D=0.268)$, Textbooks/journals $(X=3.90, S D=$ $0.218)$, patents/standards $(X=3.90, S D=0.220)$ and Newspapers/magazines $(X=3.90, S D=0.222)$.

Table 4 Mean scores of information sources utilization in decision-making of the respondents

\begin{tabular}{llll}
\hline Information Sources & $\mathbf{X}$ & SD & Variance \\
\hline Colleagues & 3.96 & 0.314 & 0.099 \\
Subordinate staff & 3.95 & 0.310 & 0.096 \\
Customers & 3.93 & 0.272 & 0.074 \\
Company files & 3.93 & 0.268 & 0.072 \\
Textbooks/journals & 3.90 & 0.218 & 0.048 \\
Patents/standards & 3.90 & 0.220 & 0.048 \\
Newspapers/magazines & 3.90 & 0.220 & 0.048 \\
Trade literature & 2.98 & 0.212 & 0.045 \\
Government publications & 2.95 & 0.198 & 0.039 \\
Reports & 2.94 & 0.199 & 0.040 \\
Internal memoranda/circulars & 2.92 & 0.188 & 0.035 \\
Company library & 2.90 & 0.182 & 0.033 \\
Electronic information services & 1.98 & 0.113 & 0.013 \\
Business/professional associates & 1.94 & 0.118 & 0.014 \\
Radio/television & 1.93 & 0.126 & 0.016 \\
Competitors & 1.90 & 0.122 & 0.015 \\
\hline
\end{tabular}

Table 4a presents mean scores of decision making behaviour of the respondents. 
Table 4A Mean scores of decision making behaviour of the respondents

\begin{tabular}{|c|c|c|c|c|}
\hline & ITEMS & $\mathbf{X}$ & SD & Variance \\
\hline I & I search for and use every available and relevant information within and outside the organization. & 4.98 & 0.081 & 0.007 \\
\hline 2 & I take delight in evaluating options that are available against objective criteria that the decision must satisfy. & .4 .98 & 0.181 & 0.033 \\
\hline 3 & I examine all possible options when considering projections and planned outcomes. & 4.97 & 0.210 & 0.044 \\
\hline 4. & I am always ready to minimize risks but take the required ones with confidence. & 4.96 & 0.341 & 0.099 \\
\hline 5. & I take decisions based on their merit not minding even my own stand on the issue. & 4.96 & 0.216 & 0.047 \\
\hline 6. & I use action reviews to discover and learn the lessons of success and failure. & 4.96 & 0.214 & 0.037 \\
\hline 7. & I put monitoring systems in place and use them to check progress. & 4.95 & 0.192 & 0.037 \\
\hline 8. & I enjoy soliciting for support before taking decisions at various stages of process. & 4.94 & 0.162 & 0.026 \\
\hline 9. & I take time to explain my decisions very well and ensure that they have been understood. & 4.94 & 0.132 & 0.017 \\
\hline 10. & I allow all the members of my team to be involved in drawing up plans for implementation. & 3.08 & 0.092 & 0.008 \\
\hline II. & I use to prepare my ideas before meetings and always stimulate others to follow my style. & 3.06 & 0.086 & 0.007 \\
\hline 12. & I encourage teams to think as a group but not as those with pre-conceived notion in issues. & 3.12 & 0.096 & 0.009 \\
\hline 13. & I take into considerations actions and reactions that affect and follow my decisions. & 4.92 & 0.211 & 0.045 \\
\hline 14. & I always try to eliminate out -of- date ideas by taking a provocative operations and innovative approaches. & 4.93 & 0.214 & 0.046 \\
\hline 15. & I employ both intellectual and lateral thinking strategies at making decisions. & 4.92 & 0.317 & 0.101 \\
\hline 16. & I use my knowledge of the work place environment and culture to get support for my decisions. & 4.91 & 0.252 & 0.0614 \\
\hline 17. & I do a thorough analysis of suggestions, and opinions of others before making up my mind on issues. & 4.91 & 0.241 & 0.058 \\
\hline 18. & I take delight in analyzing the kind of decision I will make at the onset of process. & 4.90 & 0.134 & 0.018 \\
\hline 19. & I am able to make a decision quickly and implement it immediately. & 4.84 & 0.216 & 0.047 \\
\hline 20. & I seek counsel from all the relevant people to get their help in reacting the right decisions. & 4.88 & 0.218 & 0.048 \\
\hline 21. & I encourage members to argue against any action plan put forward. & 3.25 & 0.198 & 0.039 \\
\hline 22. & I always encourage others to be involve in the decision making process. & 3.15 & 0.092 & 0.008 \\
\hline 23 & I empower others to take decisions on issues that do not concern me. & 2.42 & 0.094 & 0.009 \\
\hline 24. & $\begin{array}{l}\text { I am always ready to be accountable for the performance of the people that are engaged in implementing } \\
\text { the plan of action. }\end{array}$ & 2.40 & 0.120 & 0.014 \\
\hline 25. & I make sure that somebody is responsible for every stage of an action plan we arrive at. & 2.12 & 0.112 & 0.013 \\
\hline 26. & I try to make sure that all my meetings and with attainable and achievable decisions. & 4.52 & 0.094 & 0.009 \\
\hline
\end{tabular}

The items that best describe the good decision - making behaviour of the respondents among others include. I search for and use every available and relevant information $(x=4.98, S D=0.08 \mathrm{I})$; I take delight in evaluating options that against objective criteria that the decision must satisfy $(x=4.98, S D=0.181)$. I examine all possible options when considering projections and planned outcomes $(x=4.97, S D=0.210)$; I am always ready to minimize risks but take the required ones with confidence $(x=4.96, S D=0.34 I)$; I take decisions based on their merit not minding even my own stand on the issue $(x=4.96, S D=0.216)$; I use action reviews to discover and learn the lessons of success and failure $(x=4.96$; $S D=0.214)$, and I put monitoring systems in place and use them to check progress $(x=4.95, S D=0.192)$.

Table 5 presents the summary of test of significance of relationship between work experience and information utilization in decision-making of the respondents. The mean score of their work experience is $X=18.5$, SD $=4.20$ years and that of their information utilization is $X=22.4, S D=3.81$. There is a significant negative relationship between work experience and information utilization in decision-making of the respondents $(r=-0.548, p<0.05)$.

Table 5 Summary of test of significant relationship between work experience and information utilization in decisionmaking of the respondents

\begin{tabular}{lcccrr}
\hline Variable & $\mathbf{n}$ & $\mathbf{X}$ & $\mathbf{S D}$ & $\mathbf{r}$ & $\mathbf{P}$ \\
\hline Work experience & 580 & 18.5 & 4.20 & 0.648 & 0.024 \\
Information utilization & 580 & 22.4 & 3.81 & & \\
\hline
\end{tabular}

Of the 580 respondents, 148(25.5\%) were managers, 367(63.3\%) were senior managers and 65 (II.2\%) were executive managers. The management cadre of the respondents is measured on a -3 point scale, that is, Executive management $=3$, senior management $=2$ and management $=1$. The mean score of management cadre of the respondents was $X=2.05, S D=0.82$ and the mean score of information utilization in decision-making of them was $X=$ $22.40, \mathrm{SD}=3.8 \mathrm{I}$. Table 6 shows the summary of test of significant relationship between management cadre and information utilization in decision-making of the respondents. The test reveals that there is a significant positive relationship between management cadre and information utilization in decision-making of the respondents $(r=0.882, p$ $<0.05)$. 
Table 6 Summary of test of significant relationship between management cadre and information utilization in decisionmaking of the respondents.

\begin{tabular}{|c|c|c|c|c|c|}
\hline Variable & $\mathbf{n}$ & $\mathbf{x}$ & SD & $r$ & $\mathbf{p}$ \\
\hline Management cadre & 580 & 2.05 & 0.82 & 0.882 & 0.046 \\
\hline Information utilization & & & & & \\
\hline
\end{tabular}

Similarly, the mean score of management cadre is $(X=2.05, S D=0.82)$ and that of information availability in decisionmaking of the respondents is $(X=18.40, S D=4.28)$. Table 7 reflects the summary of test of significant relationship between management cadre and information availability in decision-making of the respondents. The test of hypothesis three shows that there is no significant relationship between management cadre and information availability in decisionmaking of the respondents $(r=0.248, p>0.05)$.

Table 7 Summary of test of significant relationship between management cadre and information availability in decision-making of the respondents.

\begin{tabular}{|c|c|c|c|c|c|}
\hline Variable & $\mathbf{n}$ & $\mathbf{X}$ & SD & $r$ & 1 \\
\hline Management cadre & 580 & 2.05 & 0.82 & 0.248 & 0.081 \\
\hline Information availability & 580 & 18.40 & 4.28 & & \\
\hline
\end{tabular}

To determine the influence of independent variables, that is, information availability and information utilization on dependent variable which is decision-making of the respondents; the overall mean scores of information sources availability, information sources utilization and decision-making of each of the respondents were computed. The multiple regression analysis was carried out on these data (see Table 8).

Table 8 Summary of regression analysis of information availability and utilization on decision-making of the respondents

\begin{tabular}{|c|c|c|c|c|c|}
\hline Source of Variation & df & SS & MS & F-ratio & $\mathbf{p}$ \\
\hline Due to regression & 2 & 2829.22 & $|4| 4.6 \mid$ & 28.98 & 0.0204 \\
\hline Due to residual & 577 & 28160.48 & 48.80 & & \\
\hline Total & 579 & 56989.70 & & & \\
\hline \multicolumn{6}{|c|}{ Multiple $\mathrm{R}$ (adjusted) $=0.8386$} \\
\hline \multicolumn{6}{|c|}{ Multiple $\mathrm{R}^{2}$ (adjusted) $=0.7032$} \\
\hline Standard Error of E & $=6.9$ & & & & \\
\hline
\end{tabular}

The test of hypothesis four shows that information availability and information utilization simultaneously do significantly influence decision-making of the respondents in the large-scale manufacturing industries in Nigeria $(F=28.98, d f=2$; $577, \mathrm{p}<0.05)$.

Table 9 shows the relative influence of each of the independent variable - information availability and information utilization on dependent variable decision-making of the respondents as reflected in the values of the regression coefficient (B), standard error of (B) estimates and T-values.

Table 9 Test of significant influence of individual independent variables on decision-making of the respondents

\begin{tabular}{llll}
\hline Variable value & \multicolumn{1}{c}{ Reg Coeff.( $(\beta)$} & \multicolumn{1}{c}{ Std. Error $(\beta)$} & T-value \\
\hline Information availability & 0.522 & 0.0684 & $8.08^{*}$ \\
Information utilization & 0.7432 & 0.0596 & $12.47^{*}$ \\
\hline Significant at $=0.05$ & &
\end{tabular}

Significant at $=0.05$

The test of hypothesis five as shown in Table 9 reveals that information availability $(B=0.5228, d f=577, T=8.08, P<$ 0.05 ) and Information utilization $(B=0.7432, \mathrm{df}=577, \mathrm{~T}=12.47, \mathrm{P}<0.05)$ do not equally influence decision-making of the respondents. In addition, information utilization has a greater influence than information availability on decisionmaking of the respondents.

Nevertheless, going by the value of multiple ' $R$ ' adjusted of 0.8386 in Table 8 . The test of hypothesis six shows that there is a significant positive multiple relationship between information availability, information utilization and decisionmaking of the respondents in the large-scale manufacturing industries in Nigeria $(R=0.8386, P<0.05)$. 


\section{Discussion}

Information is tangible and intangible goods and when consumed or used is capable of increasing knowledge state of the users like business managers in the manufacturing industries and enable them to make better decisions. Jose (1995) views it as a commodity that can be treated like any other product produced by a company and is capable of being marketed. The implication of this is that information is a tradable commodity that can be bought and sold in the product market. Even when the price of acquiring it is free somebody is paying the price because it costs much to collect, process, store and organize information for consumers' use.

However, this study finds that industry information, company information, legal or regulatory information, economic forecasts, information on technology and population matters are very highly needed information in decision-making of the respondents in the large-scale manufacturing industries in Nigeria. This finding agrees with Marshall (1993)report that managers and executive managers in five major financial institutions in Canada need industry information, company information, numeric data, legal information and other type of information in their corporate decision-making.

Folkmans (1996) asserts that business information can involve a wide range of resources from business dictionaries, bibliographies and directories to specialized products on mergers and acquisitions, risk measurement or economic forecasts, company information, market research, statistics and forecasts.

In actual fact, managers in business organizations can source their needed information from personal and impersonal sources available to them when performing their functions. Stevenson (1969) is of the view that formal sources were clearly the major source of information on the internal state of the organization, while personal sources were the major source for external information. This study therefore finds that customers, colleagues, subordinate staff, trade literature, company library, newspaper/ magazines, textbooks/journals, company files and electronic information services are very readily available and major sources of information in decision-making of the respondents in large-scale manufacturing industries in Nigeria. For information to provide knowledge and improve decision-making of managers in business organizations like the manufacturing industries, relevant sources of information capable of meeting their information needs must be readily made available to them. Moreover, in business organizations, the strategic information that are pertinent to the success or failure of the organization such as debt stock, profit volume, product development, research and development efforts, marketing management plan, etc. are tagged classified information. These types of information are not made available to all categories of personnel except those at executive management level. In most cases, access to it is strictly by authorization.

This study also reveals that colleagues, subordinate staff, customers, company files, textbooks/journals, patents/ standards, newspapers/magazines are very highly utilized sources of information in decision-making of the respondents. This finding concur with early studies by Aguilar (1967); Collings (1968) and Keeqan (1976) who report from their studies on how company executives obtain information and conclude that subordinates are the greatest single source of their information, while superiors and meetings are very poor sources of their information. Similalry, Smeltzer, Fann and Nikolaisen (1988) analyzing the scanning practices of small business managers in the phoenix and Kansas City metropolitan areas and found that personal sources are significantly more important than impersonal ones. They conclude that family members and customers are the most prevalent personal sources, while magazines and journals are the most prevalent impersonal sources of information used.

This study also finds that work experience has a significant negative relationship with information utilization in decision-making of the respondents. This implies that the lower the years of working experience of the respondents, the more they make use of information in their decision-making. This present study reveals that there is a significant positive relationship between management cadre and information utilization in decision-making of the respondents in large-scale manufacturing industries in Nigeria. This means that the higher a manager goes along the hierarchy of management, the more he/she makes use of information in his/her decision-making. In the real sense, as managers go up along the management ladder in any business organization like manufacturing company, their job performance becomes complex and decision-making become herculean task that calls for intensive use of information for rational decisions-making.

Similarly, the present finding in this study that information availability in decision-making has no significant relationship with management cadres of the respondents does not spark much surprise. The reason being that different sources of information that are internally and externally determined in the business environment of the respondents are available for their use but the problem is that of ease of access to them in their decision analysis. In a nutshell, information availability in decision-making of managers in the large-scale manufacturing industries in Nigeria is independent of their management cadre. This finding supports an early study of Kefalas and Schoderbek (1973) that executives' hierarchical level is not related to acquisition and use of information to monitor and evaluate event in their business environment in order to chart the company's future course of action. 
Nonetheless, it is also found that information availability and information utilization simultaneously do have significant influence on decision-making of the managers in the sampled large-scale manufacturing industries in Nigeria $(F=28.98$, $\mathrm{df}=2 ; 577, \mathrm{P}<0.05)$. This could not have occurred due to chance because about 70.32 percent of the total variation in the decision-making of managers in the large-scale manufacturing industries in Nigeria is accounted for by a linear combination of their information availability and information utilization. Further investigation shows that information availability and information utilization independently has a significant influence on decision-making of the respondents. Nevertheless, information utilization is found to have greater relative influence $(B=0.7432, \mathrm{df}=577, T=12.47$, $\mathrm{P}<0.05)$ than information availability $(B=0.5228, \mathrm{df}=577, \mathrm{~T}=8.08, \mathrm{P}<0.05)$ on decision-making of the managers in the large-scale manufacturing industries in Nigeria.

Furthermore, it is found that there exists a significant positive multiple relationship between information availability, information utilization and decision-making of the managers in the large-scale manufacturing industries in Nigeria $(\mathrm{R}=0.8386, \mathrm{P}<0.05)$. This implies that the more information is made available and used by the managers in the largescale manufacturing industries in Nigeria, the more their decision-making is improved and better decision is made. This finding is not at variance with that of Okwilagwe (1995) who reports that there is a significant positive relationship between the use of core-information sources and organizational effectiveness of directors and senior managers (decisionmakers) in the Nigerian publishing organizations. It must be noted that at this premise that organizational effectiveness of any business firm could be determined by improved productivity, profit making, increased sales volume or revenue, efficient resource allocation, adaptability and flexibility, improved decision-making or effective decision-making, solid liquidity base called good capitalization, good customers' relations, and good industrial relations.

\section{Conclusion and recommendations}

Information is an economic resource that is highly demanded for the production of goods and services in business organizations. Managers in industrial organizations like manufacturing industries need it for improved task performance and decision analysis. Despite the fact that managers in business organizations in Nigeria live and work in an informationrich environment, not all needed information are available for their decision-making. Beside this, their task complexity that requires rational decision-making put much pressure on them to search for relevant, reliable and accurate information and use it in their decision-making process. Among the major findings of this study are:- information availability and information utilization simultaneously and independently have significant influence on decision-making of the respondents; information utilization has a greater relative influence than information availability on decision-making of the respondents, and information utilization has a significant positive relationship with management cadre of the respondents in the large-scale manufacturing industries in Nigeria. Based on these findings, it is recommended that the board of management in the studied manufacturing industries in Nigeria must make available a wide range of information resources for the decision-making of their managers. The managers in the large-scale manufacturing industries in Nigeria should intensify their efforts in making intensive use of information in their decision-making process. The corporate library in those manufacturing companies should embark on users' education programme to improve information handling skills of the managers; and to stimulate their usage of library information products and services for decisionmaking. Access to the internet that has tremendous merits for effective information accessibility and utilization should be intensified as electronic sources of information scored very low.

\section{References}

Abels, E. (2002) Environmental Scanning. Bulletin of the American Society for Information Science 28(3): 145-I8I.

Adelabu, A. and Adisa, M. (2003) Information Resource Utilization by Managers in Pharmaceutical companies in Nigeria. Journal of Applied Management 10(2): 70-98.

Alli, M.A. (2000) Managers Use of Information in Industry. Library and Information Science Research 10(2). I I 2-I 26.

Aguilar, F.J. (1967) Scanning The Business Environment. New York, NY: Macmillan Co.

Aiyepeku, W.O. (1978) The Information Component In Decision- Making. A Framework For Analysis. The Journal Of Administration, XI I (2): I27-I29.

Aiyepeku, W.O. (1989) Information Priorities for Organizational Effectiveness. A Paper Presented at The National Workshop on Information Dissemination And Crisis Management in Organizations. Ibadan: University of Ibadan, $24-27^{\text {th }}$ July, pp. I-24.

Akhtar, S. \& Mellesse, M. (1994) Africa Information and Development: IDRC's Experience. Journal of Information Science, 20 (5) : $314-322$

Appleby, R. C. (1994) Modern Business Administration, $6^{\text {th }}$ Edition. London: Financial Times.

Auster, E. \& Choo, W.C. (1994) CEOs, Information and Decision-Making: Scanning The Environment for Strategic Advantage. Library Trends, 43(2): 206 - 225

Brewer, E. \& Tomlinson, J.W.C. (1964) The Manager's Working Day. Journal of Industrial Economics, 12 (3): 191 - 197

Collings, R.F. (1968) Scanning the Environment For Strategic Information. Unpublished Ph.D. Thesis, Harvard Business School, Cambridge, MA. 
Eyitayo, S.A. (1998) Information For Living: The Need for Community Resource Database System in Nigeria. Nigerian Libraries, $32(1): I-12$

Folkmans, A. (1996) Discover Business Information. Managing Information 3 (5): 31 - 34.

Gorry, G.A; Scott, M. \&. Micheal, S. (197I) Framework for Management Information Systems. Sloan Management Review, 13 : $55-70$.

Grosser, K. (199I) Human Networks in Organizational Information Processing. In Williams, M. A. (ed.). Annual Review of Information Science and Technology, Vol. 26. Medford, NJ: Learned Information, Inc. for the American Society For Information Science.

Hammed, A. (2002) Workers Behavior Assessment Battery: Decision-Making Behavior Inventory. Ibadan: Stirling - Horden Publishers (Nig.) Ltd.

Huber, G.L. \& Daft, R.L. (1987) The Information Environments of Organizations. In: Jabin, F.M. et al. Handbook of Organizational Communication: An Interdisciplinary Perspective. Newbury Park, CA: Sage.

Jose, A. (1995) Marketing and Libraries. Herald Of Library Science, 34 (3/4): $231-234$.

Kanter, R.M. (1989) The New Managerial Work. Harvard Business Review 67(6): 85-92.

Katzer, J. \& Fletcher, P. (1992) The Information Environment Of Managers. In: Williams, M. E. (ed.). Annual Review of Information Science and Technology, Vol. 27. Medford, N. J. Learned Information, Inc. For The American Society for Information Science.

Keegan, W.J. (1976) Scanning the International Business Environment: A Study of the Information Acquisition Process. Unpublished Ph.D Thesis. Cambridge, MA: Harvard University

Kefalas, A. \& Schoderbek, P.P. (1973) Scanning the Business Environment: Some Empirical Results Decision Sciences, 4 (I) 63 74.

Mabawonku, I. M. \& Oladele, B. A. (200I) Providing Information for Advocacy: The Emerging Role of Libraries and Information Centers in Nigeria. Nigerian Library And Information Science Review, 19 (1/2): 25 - 32.

Marshall, J.G. (1993) The Impact of Special Library on Corporate Decision-Making. Washington, DC: Special Libraries Association.

Miller, P.M. (1994) The Relationships Between Organizational Culture And Environmental Scanning: A Case Study. Library Trends, 49 (2): $170-205$

Mcfarland, D.E. (1964) Management Principles and Practices, $4^{\text {th }}$ Ed. New York: Macmillan Publisher.

Naylor, B. (1988) The Convergence Of The Library And The Computing Service: The Central Issues. British Journal Of Academic Librarianship, 3(3): $172-185$.

Norton, B. (1999) Managing Information In A WEEK. London: Hodder \& Stoughton.

Okwilagwe, O.A. (1995) Information Input as a Factor in Organizational Effectiveness of the Publishing Industry in Nigeria. Unpublished Ph.D Thesis. Ibadan: University of Ibadan

Okwilagwe, O.A. (2000) Information Service Packages Preferred by Managers in Book Publishing Organizations in Nigeria. African Journal of Educational Planning and Policy studies, I (2): I43-I5I.

Olatunji, O.A. (1994) Availability and Utilization of Information Sources and Services In Cadbury Nigeria Plc., Lagos. Unpublished MLS Dissertation. Ibadan: University of Ibadan.

Opeke, R.O. (1984) Information Consciousness as a Factor in Organizational Decision-Making: The Case of Ogun State Ministry of Education. Unpublished Ph.D Thesis. Ibadan: University Of Ibadan.

O' Reilly, C.A. \& Pondy, L.R. (1979) Organizational Communication. In: Kerr, S. (ed.) Organizational Behavior. Columbus, OH: Grid Publishing.

Pellow, A. \& Wilson, T. (1993) The Management Information Requirements of The University Departments: A Critical Success Factors Approach. Journal of Information Science, 19 (6): 425-437.

Perkins, W.S. \& Rao, R.C. (1990 The Role Of Experience In Information Use And Decision-Making By Marketing Managers. Journal of Marketing Research, 27 (I) I - 10

Popoola, S.O. (1993) Organizational Communication and Information Needs of Civil Servants in the Office of Planning And Budget, Secretariat, Ibadan, Oyo State. Unpublished MLS Dissertation Ibadan: University of Ibadan.

Popoola, S.O. (1996) Statistical Information Needs of Industries in Nigeria. African Journal For The Psychological Study Of Social Issues, 3 (I) $24-38$

Popoola S.O. (2002a) Information and Development. Ibadan: Center for External Studies Series University of Ibadan

Popoola S.O. (2002b) Female Managers' Information Input to Decision-Making in Oil companies in Nigeria. Nigerian Library and information science Trends, I (I) $69-78$.

Robson, W. (1997) Strategic Management \& Information Systems, $2^{\text {nd }}$ Ed. London: Pitman Publishing.

Smeltzer, L.R. Fann, G.L. \& Nikolaisen, V.N. (1988) Environmental Scanning Practices in Small Business. Journal of Small Business Management, 26 (3): 55-62.

Sawyer, O.O. (1993) Environmental Uncertainty and Environmental Scanning Activities of Nigerian Manufacturing Executives: A Comparative Analysis. Strategic Management Journal 14(4): 287-299.

Stevenson, H.H. (1969) Defining corporate Strengths and Weaknesses: An Exploratory Study. Unpublished Ph.D Thesis. Cambridge, MA: Harvard Business School.

Tiamiyu, M.A. (1990) Factors Underlying the Use of Information Sources in Government Institutions in Nigeria. Unpublished Ph.D Thesis. Ontario: University of Western Ontario.

Tyler, B.B. \& Bettenhausen, K.L. (1989) The Use of Low and High Risk Information Sources And Communication Channel in Developing and Implementing Competitive Business Strategy. Paper Presented At The 1989 Academy of Management Meeting Washington, DC.

SA JnI Libs \& Info Sci 2006, 72(I) 